\title{
Pengaruh Program Kepemilikan Saham Karyawan Terhadap Kinerja Keuangan Perusahaan Publik di Indonesia
}

\author{
Violia Els ha Melinda, Madeline Lestari, Sammy Kristamuljana, *Rathria Arrina Rachman \\ Sekolah Bisnis dan Ekonomi - Universitas Prasetiya Mulya \\ BSD City Kavling Edutown I.1 , Jl. BSD Raya Utama, BSD City, Tangerang 15339
}

\section{Keywords: \\ agency theory, agency problem, employee stock ownership, profitability, Indonesia}

\section{Kata Kunci:}

agency theory, agency problem, employee stock ownership, profitability, Indonesia

\section{* Corresponding Author:}

rathria.rachman@pmbs.ac.id

\begin{abstract}
Based on the Agency Theory, management (agent) is a party that is trusted by shareholders (principals) to manage the company and maximize shareholders' value (Jensen and Meckling, 1976). In practice, conflicts between shareholders and managers are unavaidable because of differences in interests and information asymmetry called Agency Problem. One way to minimize agency problem is by applying Employee Stock Ownership Program (ESOP) which gives rights to company's employees to own company's share. Through ESOP, employees are expected to improve the performance and value of the company due to their stock ownership. The purpose of this study was to analyze the effect of the implementation of the ESOP program on company financial performance especially profitability as measured by ROE (Return on Equity) and ROA (Return on Assets). This study analyzes 62 listed companies in Indonesia adopting ESOP for the first time over 2009-2016. By using panel data regression method, the results of the study show that ESOP program has a significant negative effect on the profitability of the company.
\end{abstract}

\section{Sari Pati}

Berdasarkan teori agensi, manajemen (agent) adalah pihak yang dipercaya oleh pemegang saham (principal) untuk menjalankan perusahaan dan memaksimalkan nilai pemegang saham (Jensen dan Meckling, 1976). Dalam praktiknya, konflik antara pemegang saham dan manajer tidak dapat dihindari karena adanya perbedaan kepentingan dan ketimpangan informasi yang disebut dengan konflik keagenan (Agency Problem). Salah satu cara meminimalisir agency problem adalah dengan menerapkan program kepemilikan saham karyawan (Employee Stock Ownership Program/ESOP) yang memberikan hak kepada karyawan perusahaan untuk me miliki saham perusahaan. Melalui ESOP, karyawan diharapkan dapat meningkatkan kinerja dan nilai perusahaan melalui kepemilikan saham mereka. Tujuan penelitian ini adalah untuk menganalisis pengaruh pelaksanaan program ESOP terhadap kinerja perusahaan dari sisi profitabilitas yang diukur dengan ROE (Return on Equity) dan ROA (Return on Asset). Penelitian ini menggunakan sampel sebanyak 62 perusahaan terbuka di Indonesia yang mengadopsi ESOP pertama kali dalam kurun waktu 2009-2016. Dengan menggunakan metode regresi data panel, hasil penelitian menunjukkan bahwa program ESOP berpengaruh signifikan negatif terhadap profitabilitas perusahaan. 


\section{Pendahuluan}

Dalam teori agensi (agency theory) dijelaskan bahwa manajemen sebagai agent direkrut dan ditugaskan oleh pemilik perusahaan atau principal untuk menjalankan aktivitas usaha perusahaan (Jensen dan Meckling, 1976). Pada prakteknya, agent dan principal memiliki perbedaan kepentingan conflict of interest) dan informasi yang asimetris (asymmetric information) sehingga seringkali terjadi konflik yang disebut sebagai masalah keagenan (agency problem). Agency problem ini perlu dikelola karena dapat merugikan perusahaan. Terdapat berbagai macam upaya yang dapat dilakukan untuk meminimalisir agency problem, salah satunya dengan memberikan porsi kepemilikan saham perusahaan kepada karyawan atau dikenal dengan Employee Stock Ownership Program (ESOP) yang bertujuan untuk menyelaraskan kepentingan karyawan dan pemegang saham.

Menurut Klein (1987), ESOP adalah rencana penangguhan keuntungan karyawan untuk mendapatkan saham perusahaan. Pengadopsian ESOP ini bertujuan untuk meningkatkan rasa kepemilikan karyawan sehingga komitmen dan produktivitas karyawan dapat meningkat. Penelitian dari Michie, et al (2002) menjelaskan bahwa penerapan ESOP mampu meningkatkan rasa kepemilikan karyawan serta komitmen terhadap perusahaan. Dengan adanya rasa kepemilikan yang semakin tinggi lewat pengadopsian ESOP, karyawan dengan kemampuan yang baik dan dapat membawa perusahaan ke arah yang lebih baik dapat dipertahankan, arus kas (cash flow) perusahaan dapat meningkat, motivasi serta kinerja karyawan dapat ditingkatkan, konflik kepentingan antara pemilik (principal) dan manajemen (agent) dapat diminimalisir, probabilitas terjadinya pergeseran kepemilikan dapat diantisipasi, serta nilai perusahaan dengan adanya pengembalian saham dapat meningkat (Anwar dan Baridwan, 2006).

Selain bermanfaat bagi perusahaan, ESOP juga bermanfaat bagi karyawan karena dengan memiliki saham perusahaan karyawan akan berusaha meningkatkan kinerja dan kompetensi dalam jangka waktu yang panjang untuk meningkatkan nilai dan jumlah kepemilikan sahamnya. Dengan 
demikian, apabila karyawan ingin menjual saham tersebut di kemudian hari, karyawan dapat memperoleh keuntungan dari selisih antara harga pasar saat menjual dengan harga beli saham perusahaan tersebut.

Penelitian yang dilakukan oleh Astika (2008) menyebutkan bahwa permasalahan pencapaian pendapatan, laba, dan nilai saham memiliki hubungan langsung dengan pengadopsian ESOP. Secara teoritis, pemberian kompensasi oleh perusahaan terhadap karyawan dengan basis saham secara tidak langsung akan menyaring tenaga kerja yang dimiliki sehingga dalam jangka panjang karyawan yang secara umum berkualitas dan memegang konsep proprietary dalam menja lankan tugas-tugas perusahaan dapat dipertahankan oleh perusahaan. Kinerja perusahaan yang baik memiliki potensi untuk meningkatkan nilai perusahaan melalui pencapaian laba yang baik sehingga memberikan sinyal positif bagi pasar dan meningkatkan harga saham (Anwar dan Baridwan, 2006).

Grafik 1. Ju mlah Perusahaan yang Mengadopsi ESOP Pertama Kali dalam Periode 2009-2016

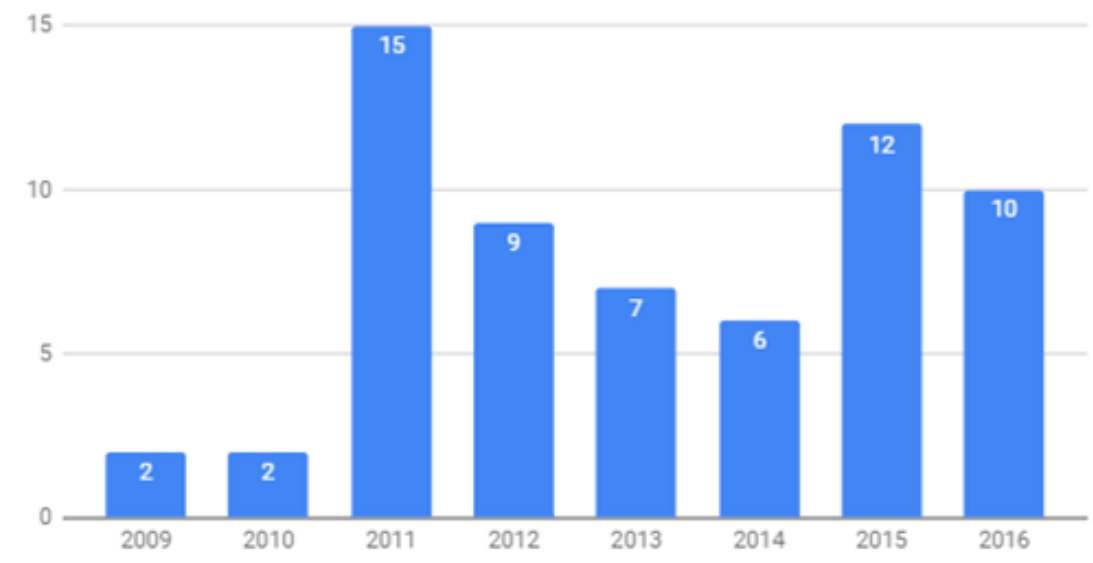

Sumber : Laporan Tahunan dan Keuangan Perusahaan, sumber data diolah

Di Indonesia, jumlah perusahaan terbuka yang mengadopsi ESOP pertama kali dalam periode 2009-2016 relatif berfluktuasi. Berdasarkan grafik 1., terdapat sekitar 12 persen atau 63 perusahaan dari total 539 perusahaan terbuka di Indonesia yang mulai mengadopsi ESOP. Pengadopsian ESOP sudah 
cukup banyak dilakukan oleh perusahaan di Indonesia, hal ini dibuktikan dengan 11 perusahaan yang termasuk LQ-45 (periode Agustus 2016-Januari 2017) yang sudah mengadopsi konsep ini.

Penelitian ini bertujuan untuk mengetahui apakah penerapan program ESOP perusahaan berpengaruh terhadap kinerja keuangan dan nilai perusahaan. Terdapat berbagai penelitian terdahulu yang menganalisa dampak ESOP terhadap kinerja perusahaan yang dilakukan di berbagai negara, namun hasil penelitian tersebut masih sangat beragam. Richter dan Scrhader (2017) meneliti 1.115 perusahaan yang berasal dari 5 negara di Eropa yaitu Jerman, Spanyol, Perancis, Italia dan Inggris dalam kurun waktu 2006 hingga 2008 dan menyimpulkan bahwa penerapan ESOP memiliki hubungan yang positif dengan kinerja keuangan perusahaan di Inggris dan Perancis namun berdampak negatif terhadap perusahaan di Jerman. Hasil penelitian yang beragam juga ditemukan di Indonesia seperti diantaranya penelitian yang dilakukan Astika dan Mardiantari dan (2015). Mereka menemukan bahwa kinerja keuangan perusahaan lebih tinggi setelah adanya pengumuman ESOP. Sementara itu, penelitian yang dilakukan oleh Hartono dan Wibowo (2014) mengatakan bahwa tidak ditemukan perbedaan antara kinerja perusahaan sebelum dan sesudah dilaksanakannya ESOP.

Oleh karena itu, studi ini ingin membuktikan apakah program ESOP dapat meningkatkan kinerja keuangan dan perusahaan di Indonesia. Dengan demikian, studi ini diharapkan dapat memperkaya literatur di bidang keuangan serta memberikan insight bagi manajemen perusahaan untuk menentukan kebijakan penerapan program kepemilikan karyawan dalam hubungannya dengan peningkatan nilai perusahaan. 


\section{Telaah Lite ratur dan Pengembangan Hipotes is}

\section{Agency Theory}

Teori Agensi (Agency Theory) menjelaskan bahwa pemilik atau pemegang saham (principal) menugaskan manajer (agent) untuk menjalankan perusahaan sesuai dengan keinginan pemilik (Jensen \& Meckling, 1976). Pada prakteknya, akan timbul konflik kepentingan antara principal dan agent (conflict of interest) yang disebut agency problem dimana pemilik perusahaan ingin memperoleh profit secara optimal dan berkelanjutan dalam jangka panjang sedangkan agent cenderung ingin mendapatkan profit dalam jangka pendek. Selain itu, terdapat pula permasalahan yang disebabkan oleh adanya information asymmetry antara principal dan agent. Information asymmetry ini terjadi karena agent terlibat langsung dalam menjalankan aktivitas usaha perusahaan sehingga memiliki informasi yang lebih banyak dan lebih baik mengenai perusahaan dibandingkan dengan principal. Oleh karena itu, validasi informasi sangat sulit untuk dilakukan sehingga tindakan yang dilakukan agent menjadi sulit untuk diawasi. Hal ini membuka peluang bagi agent untuk mendahulukan kepentingan dirinya sendiri dengan mengambil keputusan yang tidak sejalan dengan kepentingan principal. Munculnya konflik-konflik tersebut dapat merugikan perusahaan karena menimbulkan agency costs yang dapat menurunkan nilai perusahan.

Salah satu cara untuk meminimalisir agency costs antara lain yaitu dengan meningkatkan kepemilikan manajerial (Curtchley dan Hansen, 1989). Kepemilikan agent ditingkatkan agar posisi manajerial sejajar dengan posisi pemegang saham. Dengan adanya peningkatan kepemilikan agent tersebut diharapkan dapat memotivasi agent untuk mengambil tindakan yang selaras dengan pemegang saham serta mendorong agent untuk berusaha semaksimal mungkin dalam meningkatkan kinerja agar keuntungan yang diperolehnya sebagai pemegang saham semakin besar. Seiring dengan meningkatnya kinerja karwayan, kinerja perusahaan pun diharapkan dapat meningkat.

\section{Employee Stock Ownership Program (ESOP) di Indonesia}


- Employee Stock Ownership Program (ESOP) adalah program yang memberikan hak kepada karyawan atas kepemilikan saham perusahaan. Alasan utama yang melatarbelakangi perusahaan menerapkan ESOP adalah untuk meningkatkan rasa kepemilikan karyawan terhadap perusahaan dengan mensejajarkan kepentingan antara pemegang saham (principal) dan manajemen/karawan (agent) sehingga dapat memberikan pengaruh yang positif pada kinerja dan profitabilitas perusahaan secara keseluruhan di jangka panjang. Di Indonesia, program ini dikenal juga sebagai Program Kepemilikan Saham bagi Karyawan (PKSK). Menurut Tim Studi Penerapan Emiten atau Perusahaan Publik di Indonesia (2002), program kepemilikan saham perusahaan atau ESOP dapat dilakukan melalui beberapa cara. Pertama, perusahaan dapat memberikan sahamnya secara cuma-cuma (stock grant), dimana pemberian saham ini bersifat hibah dari perusahaan kepada karyawan. Kedua, melalui Program Pembelian Saham oleh Karyawan (Direct Employee Stock Purchase Plan) dimana umumnya saham perusahaan ditawarkan kepada karyawan dengan harga yang lebih murah atau harga diskon. Ketiga, melalui Program Opsi Saham (Stock Option Plan) dimana perusahaan memberikan pilihan (opsi) kepada karyawan untuk membeli saham perusahaan pada periode tertentu dengan harga tertentu. Keempat, melalui Employee Stock Option Plan dimana program ini merupakan salah satu program pensiun bagi karyawan. Kelima, perusahaan memberikan Phantom Stock and Stock Appreciation Right (SAR) yaitu hak karyawan untuk mendapatkan penambahan nilai nominal atas kepemilikan saham tanpa harus sesungguhnya memiliki saham tersebut. Keenam,melalui program Management and Employee Stock Allocation (MESA) dimana karyawan diberikan sejumlah alokasi saham dalam jumlah tertentu saat Penawaran Umum Perdana saham.

\section{Penelitian Terdahulu}

Dampak positif dari penerapan ESOP ditemukan oleh Astika dan Mardiantari (2015) di Indonesia dari pengujian terhadap 53 perusahaan publik di Indonesia yang mengumumkan dan menerapkan 
pelaksanaan ESOP pada tahun 2000 hingga 2012 dilakukan dengan menggunakan metode paired t-test dan regresi. Mereka menemukan bahwa rasa memiliki atau sense of belonging karyawan semakin meningkat setelah adanya ESOP sehingga karyawan termotivasi untuk berkomitmen tinggi dan loyal kepada perusahaan tempatnya bekerja. Dengan menggunakan paired sample test, Aribawa (2016) juga menemukan bahwa terdapat perbedaan rata-rata EVA yang signifikan sebelum dan sesudah implementasi program ESOP. Penerapan ESOP terbukti memberikan dampak yang positif terhadap economic value added (EVA) pada 17 perusahaan di Indonesia pada tahun 2004 hingga 2009. Fang et al (2015) dalam penelitiannya di Cina menemukan bahwa penerapan ESOP berdampak positif terhadap kinerja perusahaan. Dengan adanya insentif terhadap karyawan dalam bentuk ESOP, produktivitas karyawan dapat meningkat sekaligus mempertahankan karyawan yang bernilai tinggi bagi perusahaan (Ittner, et al. 2003). Selain itu, adanya program ESOP terbukti dapat meningkatkan daya tarik untuk merekrut karyawan yang berkualitas (Lazear, 1986).

Sementara itu, Richter dan Schrader (2017) melakukan penelitian dengan 1.115 sampel perusahaan di 5 negara di Eropa yaitu Jerman, Spanyol, Perancis, Italia dan Inggris pada tahun 20062008. Mereka menemukan bahwa terdapat hubungan positif antara penerapan ESOP dengan kinerja keuangan perusahaan di Inggris dan Perancis. Hal ini disebabkan insentif pajak yang diberikan pemerintah Inggris dan kultur institusi di Perancis yang mendukung sistem profit sharing (Lowitzch \& Hashi, 2009). Namun demikian, mereka juga menemukan bahwa ESOP memberikan dampak negatif bagi kinerja keuangan perusahaan di Jerman. Efek negatif tersebut disebabkan karena peraturan yang berlaku di Jerman terlalu ketat sehingga mengurangi keuntungan dari pengadopsian ESOP. Penelitian Kim dan Patel (2017) terhadap 31 perusahaan di Eropa tahun 2006-2014 juga menunjukkan bahwa penerapan ESOP memiliki dampak positif yang signifikan namun relatif rendah terhadap kinerja perusahaan. Kurang kuatnya pengaruh tersebut disebabkan karena efektivitas pengaruh kepemilikan saham bergantung pada berbagai faktor la innya seperti negara, industri, tahun, dan internal perusahaan. 
Bertolak belakang dengan hasil penelitian sebelumnya, Septarina dan Priyadi (2013) menemukan bahwa kinerja keuangan perusahaan satu tahun setelah pengadopsian ESOP mengalami penurunan apabila dibandingkan dengan kinerja keuangan perusahaan satu tahun sebelum pengadopsian ESOP. Di sisi lain, penelitian Meng et al (2011) dalam penelitiannya menemukan bahwa kinerja keuangan perusahaan, produktivitas, maupun valuasi saham antara perusahaan yang mengadopsi ESOP maupun yang tidak mengadopsi ESOP tidak memiliki perbedaan yang signifikan. Hal ini disebabkan karena saham dalam bentuk ESOP umumnya dialokasikan kepada karyawan dalam jumlah yang besar sehingga program tersebut tidak efektif untuk memotivasi karyawan dalam bekerja. Hubungan yang tidak signifikan antara ESOP dan kinerja keuangan perusahaan ini juga ditemukan dalam penelitian Hartono dan Wibowo (2014) dan Isbanah (2015). Mereka berpendapat bahwa tidak signifikannya pengaruh ESOP ini disebabkan karena jumlah kepemilikan saham yang dimiliki oleh karyawan dinilai terlalu kecil untuk memberikan dampak yang signifikan terhadap kinerja perusahaan dimana rata-rata kepemilikan saham oleh karyawan hanya sebesar 5\% dari total seluruh saham yang beredar di Indonesia.

\section{Hipotesis Penelitian}

Hipotes is yang akan diuji dalam penelitian ini adalah apakah penerapan ESOP memberikan dampak positif terhadap kinerja keuangan perusahaan dari sisi profitabilitas yang diukur dengan rasio Return on Equity dan Return on Asset.

$\mathrm{H}_{1 \mathrm{a}}$ : Penerapan ESOP berpengaruh positif terhadap ROE perusahaan

$\mathrm{H}_{1 \mathrm{~b}}$ : Penerapan ESOP berpengaruh positif terhadap ROA perusahaan

\section{Metode Penelitian}

Populasi dan Sampel

Penentuan sampel dalam penelitian ini dilakukan dengan metode purposive sampling yaitu 
perusahaan yang terdaftar di Bursa Efek Indonesia yang sudah melakukan program ESOP pada tahun 2009-2016 dan menerbitkan laporan keuangan secara lengkap. Secara keseluruhan, terdapat 62 perusahaan yang berasal dari 9 industri berbeda sebagai sampel dari total 539 perusahaan yang terdaftar di Bursa Efek Indonesia (BEI) pada tahun 2016 yaitu berasal dari basic industry \& chemical, consumer goods, trade, services \& investment, infrastructure, utility \& transportation, property, real estate, \& construction, mining, agriculture, financial, dan miscellaneous.

Sumber data berasal dari laporan keuangan dan laporan tahunan yang diakses mela lui B loomberg Terminal dan website BEI. Jenis data yang digunakan adalah data panel yang merupakan gabungan dari data time series dan cross section sehingga memiliki keunggulan diantaranya mampu mengontrol heterogenitas dari individu, memberikan informasi yang lebih lengkap dan lebih efis ien, mengidentifikasi efek yang tidak dapat dideteksi oleh data cross section atau time series, dan dapat digunakan untuk menguji metode yang lebih rumit (Baltagi, 2010).

Pelaksanaan ESOP di Indonesia terbagi menjadi Employee Stock Option Program (ESOP), Management Stock Option Program (MSOP), Management and Employee Stock Option Program (MESOP) serta Employee Stock Allocation (ESA) dan Management and Employee Stock Allocation (MESA). Dari total keseluruhan 62 perusahaan yang menjadi sampel penelitian ini terdiri dari $61.5 \%$ perusahaan yang melakukan ESOP/MSOP/MESOP, 33.8\% perusahaan yang me lakukan ESA/MESA dan $4.6 \%$ perusahaan yang melakukan MESA dan MESOP.

\section{Operasionalisasi Variabel}

Penelitian ini menggunakan variabel dependen atau variabel bebas yaitu pengadopsian ESOP. Jika perusahaan menerapkan ESOP ditandai dengan nilai 1 sementara jika tidak menerapkan ESOP maka ditandai dengan nilai 0. Selain itu, variabel independen atau variabel terikat yang digunakan dalam penelitian ini adalah rasio profitabilitas, yaitu Return on Equity (ROE) dan Return on Asset (ROA).

Return On Equity (ROE) mengukur kemampuan suatu perusahaan untuk menghasilkan laba dari 
modal ekuitas yang dimiliki. Semakin tinggi ROE, maka semakin efisien pula perusahaan tersebut memanfaatkan modalnya untuk menghasilkan laba dan sebaliknya. Septarina dan Priyadi (2013) menemukan bahwa ROE perusahaan satu tahun dan dua tahun setelah mengadopsi ESOP mengalami penurunan apabila dibandingkan dengan satu tahun sebelum ESOP diadopsi. Penelitian Meng et al.. (2011) mendapatkan hasil bahwa pengadopsian ESOP tidak berpengaruh signifikan terhadap ROE perusahaan, demikian pula hasil yang ditemukan oleh penelitian yang dilakukan oleh Isbanah (2015). Penelitian yang dilakukan oleh Hartono dan Wibowo (2014) menemukan hasil bahwa pengadopsian ESOP menghasilkan peningkatan pada nilai rata-rata ROE.

ROE dihitung dengan rumus berikut:

$$
R O E=\frac{\text { Net income }}{\text { Total shareholder's equity }}
$$

Return On Asset (ROA) mengukur kemampuan perusahaan dalam menghasilkan laba dengan menggunakan total aset yang dimiliki. Semakin tinggi nilai ROA, menunjukkan bahwa perusahaan semakin efisien dalam memanfaatkan aset untuk menghasilkan laba. Penelitian yang dilakukan oleh Septarina dan Priyadi (2013) mendapatkan hasil bahwa ROA perusahaan satu tahun dan dua tahun setelah mengadopsi ESOP menurun apabila dibandingkan dengan sebelum pengadopsian ESOP. Penelitian dari Meng et al.. (2011) menunjukan bahwa pengadopsian ESOP tidak memiliki pengaruh yang signifikan terhadap ROA perusahaan, demikian pula hasil yang ditemukan oleh penelitian yang dilakukan oleh Isbanah (2015). Penelitian yang dilakukan oleh Hartono dan Wibowo (2014) menunjukan bahwa pengadopsian ESOP menghasilkan peningkatan pada nilai rata-rata ROA.

ROA dihitung dengan rumus berikut:

$$
R O A=\frac{\text { Net income }}{\text { Total assets }}
$$

Penelitian ini juga menggunakan variabel kontrol yang terdiri dari ukuran perusahaan (size), 
kepemilikan institusi (institutional ownership) serta rasio utang (leverage ratio). Ukuran atau skala perusahaan dapat memberikan efek yang signifikan terhadap kinerja perusahaan karena semakin besar ukuran perusahaan dapat meningkatkan skala ekonomi dan mengurangi biaya pengumpulan dan pemrosesan informasi sehingga meningkatkan kinerja keuangan perusahaan (Astuti, 2003; Baridwan dan Zuhrotun, 2005). Penelitian ini menggunakan log dari total aset sebagai pengukuran ukuran atau skala perusahaan (Blasi, et al., 1996; Kimberly, 1976).

Kepemilikan institusional (INS) terbukti memiliki hubungan positif yang signifikan dengan performa perusahaan. Hal ini disebabkan karena semakin banyak saham perusahaan dimiliki oleh institusi akan semakin mendorong pengawasan yang lebih ketat oleh investor institusional sehingga dapat meminimalisir kemungkinan munculnya perilaku oportunistik manajer yang dapat merugikan perusahaan dan mempengaruhi profitabilitas perusahaan (Lin et al, 2017; Sujoko dan Soebiantoro, 2007). Kepemilikan institusi dihitung dengan membandingkan antara jumlah saham yang dimiliki investor institusi dengan jumlah saham yang beredar.

Rasio utang (leverage ratio) mengukur banyaknya utang yang digunakan sebagai sumber dana perusahaan untuk memperoleh aset. Semakin tingi rasio utang semakin besar pula resiko perusahaan gagal bayar yang meningkatkan risiko kebangkrutan perusahaan. Namun demikian, semakin tinggi rasio utang menunjukan bahwa semakin besarnya peluang perusahaan untuk memiliki aset yang lebih banyak dimana aset tersebut dapat digunakan untuk memperoleh keuntungan yang pada akhirnya dapat meningkatkan profitabilitas perusahaan. Dalam penelitian ini, rasio utang dihitung dengan menggunakan Debt to Equity Ratio (DER) yang mengindikasikan berapa banyak hutang yang digunakan oleh perusahaan terhadap total shareholder's equity.

DER dihitung dengan formula sebagai berikut:

Debt to Equity Ratio $=\frac{\text { Total Debt }}{\text { Total Equity }}$ 


\section{Model Penelitian}

Penelitian ini menggunakan variabel ROE dan ROA sebagai indikator untuk mengukur kinerja perusahaan dari sisi profitabilitas sehingga model dari penelitian ini adalah sebagai berikut:

$$
\begin{aligned}
& R O E_{i t}=\alpha+\beta_{I} S O_{i t}+\beta_{2} S I Z E_{i t}+\beta_{3} I N S T_{i t}+\beta_{4} D E R_{i t}+e \\
& R O A_{i t}=\alpha+\beta_{1} S O_{i t}+\beta_{2} S I Z E_{i t}+\beta_{3} I N S T_{i t}+\beta_{4} D E R_{i t}+e
\end{aligned}
$$

Keterangan:

ROE $=$ Return on Equity

ROA $=$ Return on Asset

$\mathrm{SO}=\mathrm{ESOP}$

SIZE $=$ u kuran perusahaan

INST $=$ persentase kepemilikan oleh institusi

DER $=$ Debt to Equity Ratio

\section{Hasil dan Diskusi}

\section{Analisa Deskriptif Statistik}

Tabel 1. Statistik Deskriptif

\begin{tabular}{|l|l|l|l|l|l|}
\hline \multicolumn{1}{|c|}{ Variabel } & \multicolumn{1}{|c|}{ N } & \multicolumn{1}{c|}{ Mean } & \multicolumn{1}{c|}{ Min } & \multicolumn{1}{c|}{ Max } & \multicolumn{1}{c|}{ Std. Dev } \\
\hline ROE & 283 & 0.0651383 & -1.99332 & 0.743811 & 0.2411245 \\
\hline ROA & 283 & 0.0353719 & -0.2897917 & 0.324936 & 0.0692495 \\
\hline SO & 283 & 0.7773852 & 0 & 1 & 0.4167387 \\
\hline SIZE & 283 & 5.676771 & 1.622901 & 8.619692 & 1.919184 \\
\hline INST & 283 & 31.93003 & 0 & 96.987 & 31.32388 \\
\hline DER & 278 & 107.9633 & 0 & 1281.592 & 161.094 \\
\hline
\end{tabular}

Berdasarkan analisa deskriptif statistik yang diperoleh, ROE memiliki nilai relatif bervariasi yang ditunjukkan dengan nilai minimum dan maksimum ROE sebesar $-199.33 \%$ dan $74.38 \%$. Selanjutnya, kinerja perusahaan yang diukur dengan variabel ROA juga memiliki nilai yang relatif bervariasi dengan 
nilai ROA terendah sebesar $-28.98 \%$ dan nilai ROA tertinggi sebesar $32.49 \%$. Selain itu, variabel independen yang digunakan dalam penelitian ini yaitu SO memiliki nilai maksimum yaitu 1 ketika perusahaan telah mengadopsi ESOP dan nilai minimum sebesar 0 ketika perusahaan belum mengadopsi ESOP (dummy variable).

Perusahaan yang termasuk dalam observasi penelitian ini relatif bervariasi jika dilihat sisi ukuran perusahaan. Hal ini ditunjukkan oleh variabel SIZE yang memiliki nilai maksimum sebesar 8.619692 dan nilai minimum sebesar 1.622901. Hal ini sejalan pula dengan variabel kontrol INST dengan nilai minimum sebesar 0 yang menunjukkan tidak terdapat kepemilikan institusi di perusahaan tersebut. Namun demikian, terdapat pula sebagian besar perusahaan yang dimiliki oleh institusi yaitu dengan nilai variabel INST sebesar 96.99\%. Di sisi lain, tingkat hutang perusahan memiliki persebaran yang relatif bervariasi. Terdapat perusahaan dengan DER sebesar 0 tetapi disisi lain terdapat perusahaan dengan nilai DER sebesar 1,281.592.

\section{Hasil Uji Regresi Pengaruh ESOP Terhadap ROE dan ROA}

Dengan menggunakan fixed effect model, hasil uji regresi antara ROE sebagai variabel dependen dan ESOP sebagai variabel independen tersaji dalam Tabel 2. Karena memiliki masalah heteroskedastisitas dan autokorelasi, metode regresi Driscoll-Kraay digunakan dan diperoleh hasil Uji-F dengan nilai Prob sebesar 0.0000 yang lebih kecil daripada alpha sebesar 0.05. Hal ini mengindikasikan bahwa variabel independen secara bersama-sama mempengaruhi variabel dependen secara signifikan. Didapatkan pula R-squared sebesar $30.73 \%$ yang menunjukan bahwa variasi pada ROE dapat dije laskan sebanyak 30.73\% oleh variasi SO, SIZE, INST, dan DER. Selain itu, hasil Uji-t di Tabel 2 menunjukan hasil bahwa variabel ESOP (SO) dan Debt to Equity Ratio (DER) menunjukkan pengaruh signifikan terhadap ROE dengan level signifikansi 1\%. Sementara itu, variabel ukuran perusahaan (SIZE) dan persentase kepemilikan institusi (INST) terbukti tidak memiliki pengaruh yang signifikan terhadap ROE. 
Lebih jauh lagi, variabel ESOP (SO) terbukti memiliki pengaruh negatif terhadap ROE dengan koefisien sebesar 0.0908184. Hal ini menunjukan bahwa dengan adanya pengadopsian ESOP menyebabkan ROE menjadi turun sebesar 0.0908184 atau 9\%. Demikian pula dengan variabel Debt to Equity Ratio (DER) yang juga memiliki pengaruh negatif terhadap ROE sebesar 0.0017657 yaitu berarti bahwa setiap kenaikan 1\% DER akan menurunkan ROE seebesar 0.0017657 atau $0.17 \%$.

Dengan menggunakan random effect model, hasil uji regresi antara ROA sebagai variabel dependen dan ESOP sebagai variabel independen tersaji dalam Tabel 2. Karena memiliki masalah heteroskedastisitas dan autokorelasi, maka regresi dilakukan dengan metode clustered robust yang menghasilkan nilai Prob sebesar 0.0001 yang lebih kecil daripada level signifikansi sebesar 0.05. Hasil Uji-F ini menunjukan bahwa ESOP dan variabel independen lainnya secara bersama-sama mempengaruhi ROA secara signifikan. Lebih jauh lagi, nilai $R$-squared sebesar $15,70 \%$ menunjukkan bahwa variasi pada ESOP, SIZE, dan DER mampu menjelaskan 15,70\% variasi yang terjadi pada ROA. Selain itu, hasil Uji-t menunjukkan adanya pengaruh pengadopsian ESOP terhadap ROA yang bersifat negatif di level signifikansi 5\%. Variabel DER juga terbukti memiliki pengaruh signifikan negatif pada level signifikansi $1 \%$ dan $10 \%$ secara berurutan. Namun, variabel SIZE dan INST terbukti tidak mempengaruhi ROA secara signifikan.

Dari hasil regresi didapatkan hasil bahwa setelah perusahaan melakukan pengadopsian ESOP maka ROA perusahaan menurun sebesar -0.030487 atau 3.05\%. Demikian pula dengan variabel DER yang memiliki pengaruh negatif terhadap ROA sebesar 0.0001535. Hasil ini menunjukan bahwa setiap kenaikan DER sebanyak 1\% menurunkan ROA sebanyak $0.00015 \%$.

Tabel 2. Hasil Uji Regresi Data Panel

\begin{tabular}{|l|c|l|c|c|}
\hline Variabel Dependen & \multicolumn{2}{|c|}{ ROE } & \multicolumn{2}{c|}{ ROA } \\
\hline & Coef & $\mathrm{P}>|\mathrm{t}|$ & Coef & $\mathrm{P}>|\mathrm{t}|$ \\
\hline SO & -0.0908184 & $0.000^{* * *}$ & -0.030487 & $0.000^{* * *}$ \\
\hline
\end{tabular}

Pengaruh Program Kepemilikan Saham Karyawan Terhadap Kinerja Keuangan Perusahaan Publik di Indonesia 


\begin{tabular}{|l|r|l|r|l|}
\hline SIZE & 0.041457 & 0.485 & 0.0013112 & 0.610 \\
\hline INST & -0.000117 & 0.809 & -0.0000926 & 0.421 \\
\hline DER & -0.0017657 & $0.000^{* * *}$ & -0.0001535 & $0.000^{* * *}$ \\
\hline Jumlah Observasi & \multicolumn{2}{|c|}{278} & 278 \\
\hline Prob > chi2 & \multicolumn{2}{|c|}{0.0000} & 0.0000 \\
\hline R-squared & \multicolumn{2}{|c|}{0.3073} & 0.1570 \\
\hline
\end{tabular}

Keterangan:

ROE $=$ Return on Equity

$\mathrm{ROA}=$ Return on Asset

$\mathrm{SO}=\mathrm{ESOP}$

SIZE $=$ u kuran perusahaan

INST $=$ persentase kepemilikan oleh institusi

DER $=$ Debt to Equity Ratio

$* * *=$ Signifikan pada $0.01, * *=$ Signifikan pada $0.05, *=$ Signifikan pada 0.1

Dari hasil uji hipotesis dengan metode regresi data panel diatas, diketahui bahwa variabel ESOP (SO) berpengaruh negatif signifikan terhadap variabel ROE dan ROA. Hal tersebut mengindikasikan bahwa ketika mengadopsi ESOP, perusahaan memiliki ROA dan ROE yang lebih rendah. Temuan hasil penelitian ini tidak mendukung hipotesis awal penelitian atau dengan kata la in pengadopsian ESOP yang dilakukan perusahaan tidak mendukung tujuan awal untuk meminimalisir agency problem. Namun demikian, penemuan ini sejalan dengan penelitian yang dilakukan oleh Septarina dan Priyadi (2013) di Indonesia serta penelitian dari Richter dan Schrader (2017) dengan sampel perusahaan di Jerman.

Pengadopsian ESOP tidak berpengaruh positif terhadap kinerja perusahaan dapat terjadi karena dua alasan. Pertama, perusahaan dengan jumlah pemegang saham yang besar memiliki performa harga saham yang cenderung fluktuatif karena dipengaruhi oleh keputusan investasi dari banyak pihak. Dengan demikian, kinerja keuangan perusahaan tidak selalu selaras dengan kinerja harga sahamnya sehingga karyawan yang memiliki saham di perusahaan tersebut kurang termotivasi untuk memaksimalkan kinerja 
individunya. Selain itu, dengan banyaknya jumlah pemegang saham di perusahaan, karyawan juga menanggung risiko berupa variasi imbal hasil (return) akibat naik-turunnya harga saham perusahaan (Richter dan Schrader, 2017).

Kedua, minimnya sosialisasi dan belum kuatnya regulasi di Indonesia menyebabkan rendahnya pemahaman karyawan mengenai manfaat dari program ESOP sehingga karyawan menjadi kurang tertarik untuk mengikuti ESOP. Dengan demikian, tujuan program ESOP untuk meminimalisir agency cost dan meningkatkan kinerja perusahaan tidak tercapai karena sosialisasi menjadi semakin sulit untuk dilakukan pada perusahaan berskala besar (Richter dan Schrader, 2017). Perusahaan yang menjadi sampel penelitian ini memiliki rata-rata total aset sebesar Rp 14.655.085.580.000 sehingga tergolong cukup besar. Peraturan yang menjadi pedoman perusahaan dalam mengadopsi ESOP di Indonesia hingga penelitian ini dilakukan bukan merupakan peraturan khusus untuk mengatur pelaksanaan ESOP. Peraturan ini adalah Peraturan BEI I-A Lampiran Keputusan Direksi PT Bursa Efek Indonesia Nomor: Kep-00001/BEI/01-2014, Peraturan Bapepam IX.A, serta Peraturan Bapepam IX.D.4. Peraturan diatas secara garis besar mengatur tentang penambahan saham baru maupun penawaran umum perdana pada perusahaan terbuka yang tidak disusun secara spesifik untuk mengatur pengadopsian ESOP. Selain itu, belum terdapat regulasi perpajakan yang mengatur pengadopsian ESOP secara spesifik hingga penelitian ini dilakukan. Peraturan perpajakan yang berlaku di Indonesia terkait pengadopsian ESOP hanya mengatur jika saham diberikan secara cuma-cuma maka akan dikenakan PPh Pasal 21 atas nilai pasar saham jika diperdagangkan di bursa atau nilai nominal jika tidak diperdagangkan di bursa. Kondisi ini bertolak belakang dengan negara maju seperti Amerika Serikat yang memberikan insentif pajak seperti yang tercantum dalam pasal 1042 IRC yaitu karyawan yang menjual kepemilikan melalui ESOP berhak memperoleh fasilitas penangguhan pajak atas capital gain. Minimnya regulasi serta peraturan perpajakan di Indonesia membuat karyawan menjadi kurang tertarik terhadap tujuan pengadopsian ESOP, sehingga pada akhirnya mengurangi dampak dari pengadopsian ESOP itu sendiri. 


\section{Kesimpulan, Implikasi, dan Keterbatasan}

Hasil dari pene litian ini menunjukkan bahwa pengadopsian ESOP terbukti menurunkan performa keuangan perusahaan yang tercermin dalam rasio profitabilitas perusahaan (ROA dan ROE). Hal ini sejalan dengan penelitian terdahulu yang menjelaskan bahwa pengadopsian ESOP pada perusahaan dengan jumlah pemegang saham yang besar dapat menurunkan insentif karyawan untuk meningkatkan performa kerja mereka karena kinerja keuangan perusahaan tidak selalu selaras dengan kinerja harga sahamnya. Selain itu, dengan banyaknya pemegang saham, karyawan juga harus menanggung risiko atas variasi imbal hasil akibat fluktuasi harga saham yang dimilikinya. Kedua, minimnya sosialisasi dan belum kuatnya regulasi di Indonesia atas program ESOP menyebabkan rendahnya pemahaman karyawan mengenai manfaat dari program ESOP sehingga karyawan menjadi kurang tertarik untuk program mengikuti ESOP.

Terdapat beberapa keterbatasan dalam penelitian ini yaitu penelitian ini tidak mengikutsertakan proporsi besaran ESOP secara total dikarenakan tidak semua perusahaan mencantumkan proporsi ESOP secara spesifik ke dalam Laporan Keuangan maupun Laporan Tahunan mereka. Keterbatasan kedua, penelitian ini hanya mengukur kinerja keuangan perusahaan dari sisi profitabilitas yang diukur dengan rasio $\mathrm{ROE}$ dan ROA.

Berdasarkan keterbatasan penelitian tersebut, saran-saran yang direkomendasikan untuk penelitian selanjutnya adalah menggunakan total besaran proporsi ESOP untuk menganalisa pengaruhnya terhadap kinerja perusahaan. Selain itu, pengukuran kinerja keuangan perusahaan dapat juga dilengkapi dengan analisa kinerja harga saham perusahaan atau market value dari saham perusahaan. Saran lainnya adalah analisa dapat dibedakan berdasarkan kategori industri untuk menangkap fenomena yang secara spesifik terjadi di berbagai industri dengan karakteristik perusahaan serta karyawan yang berbeda. 


\section{DAFTAR PUSTAKA}

Anwar, A. \& Baridwan, Z. (2006). Effect of Employee Stock Option Plans (ESOPs) to performance and Firm Value: Empirical study at JSX, Jurnal dan Prosiding SNA, Simposium Nasional Akuntansi.

Aribawa, D. (2016). Analis is Nilai Perusahaan pada Implementasi Program Kepemilikan Saham pada Karyawan/Manajemen. Jurnal Ekonomi Dan Bisnis, 19(3), 341-354.

Astika, I, B, P. (2008). Pembentukan Return Saham Ekspektasian melalui Managemen Laba di sekitar Peristiwa Pengumuman Program Opsi Saham Karyawan. Jurnal Aplikasi Manajemen, 8 (3), 827835.

Astika, I.B.P \& Mardiantari, N.P.E. (2015). Kinerja Keuangan Perusahaan di Sekitar Peristiwa Pengumuman ESOP dan Pengaruhnya Pada Nilai Perusahaan. Jurnal Akuntansi Universitas Udayana, 13(2), 532-548.

Astuti, S. (2003). Pengaruh Laporan Keuangan Terhadap Peringkat Hutang (BondRating) Studi Empiris pada Perusahaan di Bursa Efek Jakarta. Wahana, 6(2), 105-112.

Baltagi, B., H. (2010). Econometrics Analys is of Panel Data. $3^{\text {rd }}$ Editiion. John Wiley \& Sons.

Baridwan, Z. \& Zuhrotun. (2005). Pengaruh Pengumuman Peringkat Terhadap Kinerja Obligasi. Simposium Nasional Akuntansi VIII, 15-16.

Blasi, J., Conte, M., \& Kruse, D. (1996). Employee Stock Ownership and Corporate Performance among Public Companies. ILR Review, 50(1), 60-79.

Crutchley, C. E. \& Hansen, R. S. (1989). A Test of the Agency Theory of Managerial Ownership, Corporate Leverage, and Corporate Dividends. Financial Management, 1(18), 36-46.

Fang, H., Nofsinger, J. R., \& Quan, J. (2015). The effects of employee stock option plans on operating performance in Chinese firms. Journal of Banking \& Finance, 1(54), 141-159.

Hartono, A., \& Wibowo, A, J. (2014). Pengaruh Employee Stock Ownership Program (ESOP) terhadap kinerja perusahaan publik di BEI, MODUS, 26(1), 85-91. 
Isbanah, Y. (2015). Pengaruh ESOP, Leverage, dan Ukuran Perusahaan Terhadap Kinerja Keuangan Perusahaan di Bursa Efek Indonesia. Jurnal Riset Ekonomi dan Manajemen, 15(1), 28-41.

Ittner, C, D. \& Larcker, D. F. \& Randall, T. (2003). Performance implications of strategic performance measurement in financial services firms. Accounting, Organizations and Society, 28(7-8), 715741.

Jensen, M. C. \& Meckling, W, H. (1976). Theory of the Firm: Managerial Behavior, Agency Cost and Ownership Structure. Journal of Financial Economics, 3(4), 305-360.

Kimberly, J, R., 1977, Organizational Size and the Structuralist Perspective: A Review, Critique, and Proposal. Administrative Science Quarterly, 22(2), 341-351

Kim, K.Y. \& Patel, P.C. (2017). Employee ownership and firm performance: A variance decomposition analys is of European firms. Journal of Business Research, 70, 248-254.

Klein, K. J. (1988). Correlates of Employee Satisfaction With Stock Ownership: Who Likes an ESOP Most?, Journal of Applied Psychology, 73(4), 630-638.

Lazear, E.P. (1986). Salaries and Piece Rates. Journal of Business, 59, 405-431.

Lin, Y. R. \& Fu, X. M. (2017). Does institus ional ownership influence firm performance? Evidence from China. International Review of Economics and Finance,49,17-57.

Lowitsch, J., Hashi, I. \& Woodward, I. (2009). The PEPPER IV Report: Benchmarking of Employee Participation in Profits and Enterprise Results in the Member and Candidate Countries of the European Union. Institute for Eastern European Studies, University of Berlin, Germany.

Meng, R., Ning, X., Zhou,X., \& Zhu, H. (2011). Do ESOPs enhance firm performance? Evidence from China's reform experiment. Journal of Banking and Finance, 35, 1541-1551.

Michie, J., Oughton, C., \& Bennion, Y. (2002). Employee ownership, motivation and productivity. Birkbeck University of London, November 2002. 
Richter, A. \& Schrader, S. (2017). Levels of Employee Share Ownership and the Performance of Listed Companies in Europe. British Journal of Industrial Relations, 55(2), 396-420.

Septarina, D., \& Priyadi, M. P., (2013). Analis is Perbandingan Kinerja Keuangan Sebelum dan Sesudah Pengadopsian Employee Stock Option Program. Jurnal Ilmu dan Riset Akuntansi, 2(7), 227-240.

Sujoko \& Soebiantoro, U. (2007). Pengaruh Struktur Kepemilikan Saham, Leverage, Faktor Interen dan Faktor Eksteren terhadap Nilai Perusahan. Jurnal Manajemen dan Kewirausahaan, 9(1), 41-48.

Tim Studi Penerapan ESOP Emiten atau Perusahaan Publik di Pasar Modal Indonesia. (2002). Studi Tentang Penerapan ESOP (Employee Stock Ownership Plan) Emiten Atau Perusahaan Publik Di Pasar Modal Indonesia. Departemen Keuangan Republik Indonesia . 